Lektorált tanulmányok

\title{
A push és a pull motivációk szerepe a magyarok szabadidős utazásai során
}

\author{
Szerzô: Hinek Mátyás ${ }^{1}$
}

A nemzetközi turizmuskutatás prosperáló területe az utazási motivációk vizsgálata. Jelen kutatás a magyar lakosság szabadidős utazásainak motivációit vizsgálja kérdőives felmérés segitségével. A vizsgálat a szakirodalomban széles körben alkalmazott push (ösztönzó) és pull (húzó) motivációs elmélet alapján történt. Az elemzés során faktoranalizis segítségével hat push és hat pull motivációt azonosítottunk. A válaszadók egyes demográfiai jellemzői alapján (nem, kor, legmagasabb végzettség, egy före jutó jövedelem) válaszadói csoportokat képeztünk, majd varianciaanalízis segitségével vizsgáltuk a motivációs különbségeket. A különféle válaszadói csoportok motivációs eltéréseinek komplex vizsgálatával négy szabadidős turisztikai szegmenst azonosítottunk, amelyek létét gyakorlati tapasztalatok, illetve a termék- és szolgáltatásmarketing egyéb példái igazolják.

Kulcsszavak: turisztikai marketing, desztinációmenedzsment, turisztikai motivációk, push és pull faktorok, piacszegmentálás.

\section{Bevezetés}

Az erősödő globális turisztikai versenyben nemcsak a kínálat fizikai elemeinek és a desztináció imázsának alakítása jelenti a kizárólagos sikertényezőt, hanem annak megértése is, hogy a turisták miért és hogyan választják ki utazásuk célpontját, melyek azok a tényezók, amelyek a desztináció-választási döntést befolyásolják. A turisztikai desztináció, mint termék, fizikai jellemzőinek és az értékesítést támogató turisztikai marketing elemeinek tudatos alakításán túl a desztinációmenedzsment akkor lehet igazán hatékony, ha megismeri és megérti a turista motivációit is. A motivációk ismerete segíthet a turisztikai piac szegmentálásában, az igényeket jobban kielégítő turisztikai termékek és szolgáltatások kialakításában, így a turista elégedettségének növelésében. Az utazási motivációk megismerése és a turista desztináció-választási folyamatának jobb megértése az eredményesebb turisztikai termékfejlesztés és marketing egyik feltétele, elősegíti a turista megtartását, ösztönzi újravásárlását, újralátogatását (FODNESS 1994, CROMPTON - McKAY 1997, UYSAL et al. 2008).

\section{Elméleti háttér}

A turisztikai motivációkkal kapcsolatos viszonylag szúk magyar nyelvú turisztikai szakirodalom

${ }^{1}$ intézetvezetö főiskolai tanár, Budapesti Metropolitan Egyetem, Turizmus és Marketing Intézet, mhinek@metropolitan.hu főként a Maslow-féle szükséglethierarchia modellt tárgyalja (MASLOW 1954, lásd például PUCZKÓ - RATZ 2011). A Maslow-modell szerint a szükséglet-kielégítés különböző hierarchikus szintjein az egyének más-más okból, eltérő motivációk hatására kívánnak utazni. A pihenés iránti vágy, a menekülés vágya, vagy magasabb hierarchiaszinten az önmegvalósítás vágya, utazásra (is) ösztönzó, belülről fakadó motivációk, amelyek az egyén szociodemográfiai és pszichológiai jellemzóiból vezethetők le, és amelyeket befolyásol a turista neme, kora, társadalmi státusza, jövedelme, és számos további tényezô. Azonban a Maslow-modell nem képes megmagyarázni, hogy a turista melyik desztinációt fogja választani és miért.

A különféle turisztikai motivációkat a hetvenes évek második felében a neobehaviorista kutató TOLMAN (1959) viselkedéspszichológiai kutatásai alapján DANN (1977, 1981, id.: BOWEN - CLARK 2009) foglalta átfogó logikai keretbe. A turisztikai motivációkkal kapcsolatos tudományos igényú vizsgálatokat áttekintve Dann arra a megállapításra jutott, hogy bár a vizsgált téma kapcsán sok a zavar, sőt esetenként azt is nehézkes megállapítani, hogy a kutatók valójában ugyanazt a jelenséget tanulmányozzák-e, de alapvetóen két szemlélet azonosítható:

- Az utazás egyfajta válaszként fogható fel a turista életéból hiányzó valamilyen szükséglet kielégítésére.

- Az utazás, a desztináció jellemzői, az ösztönzô motivációkra válaszul húzzák (vonzzák) a turistát.

A két megközelítés a turisztikai motivációk két csoportját képviselik, amelyet Dann Tolman ka- 
Lektorált tanulmányok

tegorizálása alapján push (ösztönzô) és pull (húzó) motivációkként azonosított. A push motivációk a belső vágyakat képviselik, ezek nyomják a turistát az utazás felé. A pull motivációk a desztináció turista által érzékelt és értékelt jellemzőii, ezek húzzák (vonzzák) a desztinációba a turistát. A desztinációs pull tényezóket a turista a saját belsố (push) motivációinak fényében értékeli.

A push (ösztönzó) tényezók a turisták és környezetük szociálpszichológiai konstrukcióinak tekinthetők, amelyek segítenek megmagyarázni az utazás iránti vágyat. A push tényezôk többsége belső motiváció, például a menekülés, a pihenés vágya, vagy a kikapcsolódás, az egészség és fitnesz, a kaland és a társadalmi interakció vágya. Ezek Maslow szükséglethierarchiájához kapcsolódnak: az önbecsülés, a valahová tartozás, az önmegvalósítás, az elismerés és a státusz iránti vágy a turista belső motivációi.

A pull (húzó) tényezók a desztináció vonzerejéból fakadóan merülnek fel, és válnak érzékelhetővé az utazási szándékkal rendelkezô turisták számára. Magukban foglalják a desztináció megfogható erőforrásait, például a strandokat, a rekreációs létesítményeket és a kulturális látnivalókat, valamint az utazók percepcióit és elvárásait, köztük az újdonság iránti vágyukat, a hasznossági elvárásaikat és a marketing által közvetített képet (McGEHEE et al. 1996). A desztináció jellemzói reagálhatnak, ösztönözhetik és megerősíthetik a belső (push) motivációkat.

A belsô (push) és a desztináció vonzerejével kapcsolatos (pull) motivációk azonosítása és szétválasztása már a '70-es évek végén megtörtént. CROMPTON (1979) szerint az egyént valamilyen rövid vagy hosszú távú egyensúlytalansági állapot, például a napi rutinból való kitörés vágya, ösztönzi változtatásra. Az egyensúlytalanság feloldására három viselkedési mintát követhet: otthon marad, szabadidôs utazásra indul, vagy egyéb célból utazik, például rokonait látogatja, esetleg üzleti útra megy. Ha az egyénben felmerült az utazás iránti vágy, a motiváció ösztönző dimenziója átalakul irányított dimenzióvá, amely a turistát a vágyott desztináció kiválasztásakor vezeti. Az alternatív desztinációk közötti választás a motivációhierarchiában éppen domináns egyedi motivációk kombinálásának intenzitásától függ, ez magyarázza, hogy az egyén ugyanarra a stimulusra (érzékelt egyensúlytalanságra) különbözô időpontokban eltérôen reagál, azaz más és más desztinációt választ. A motivációk egy kontinuum mentén rendezhetők el, amelynek az egyik felére szociálpszichológiai motivációk, míg a másikra kulturális motivációk kerültek.
A szociálpszichológiai motivációk szerepére jellemző, hogy maga a desztináció adott esetben nem is fontos, az úti cél csupán a motiváció(k) kielégítésének eszköze. Szociálpszichológiai motiváció például a menekülés vágya, az egyéni újrafelfedezés és újraértékelés vágya, a pihenés, a presztízs, a nosztalgia, a családi kapcsolatok ápolásának vágya, vagy a társadalmi interakciók erősítése. Mivel ezek a faktorok nem egy adott jellemzókkel leírható fizikai helyhez köthetők, így ezek belső, push motivációk.

A motivációs kontinuum másik oldalán elhelyezkedő kulturális tényezők inkább a desztináció jellemzői, és kevésbé kapcsolódnak az egyén szociálpszichológiai helyzetéhez. Crompton mindössze két kulturális motivációt azonosított, az újonságot, amelyen különlegességet, kalandot, az újat és a különbözőt érti, valamint az oktatást és tanulást, amely az utazás során történó tapasztalatszerzést jelenti. A kulturális motivációk így a pull tényezőknek feleltethetők meg, ezek jellemzően a desztináció sajátosságaitól függenek.

Habár a push és a pull besorolás egyszerú, és úgy túnik, hogy minden motivációt magában foglal, azonban nem szükséges ezeket a tényezôket egy dichotómia két végpontjának tekinteni. A push és pull faktorok a fogyasztó agyában egybeolvadnak (GOOSSENS 2000). A turista saját maga hozhatja létre a saját egyensúlyát a megszokottól, a világtól való menekülés és a csábító új között. ISO-AHOLA (1982) szerint „általában mindkét megközelítés (keresés) és elkerülés (menekülés) komponense jelen van a szabadidős motivációban (...) és a turisztikai motivációban különösen." Másképp fogalmazva a push és pull faktorok nem két különböző időpontban meghozott elkülönült döntések alapjául szolgálnak, hanem az egyén döntésében mindkét motiváció egyszerre vesz részt. Továbbá minden motivációnak van egy személyes (pszichológiai) és interperszonális (társadalmi, szociális) komponense, így már négy motivációs dimenzió bukkan fel, a személyes menekülés, a személyes keresés, az interperszonális menekülés és az interperszonális keresés (ISO-AHOLA 1983).

Újabb keletú motivációs modell az utazási karrier minta (travel career pattern, TCP), amely az utazási motivációk push tényezőit csoportosítja és rendeli hozzá turisták csoportjaihoz (PEARCE 2005, PEARCE - LEE 2005, DOLNIKAR et al. 2012). Attól függóen, hogy az utazó milyen korú, melyik életszakaszában jár, és milyen utazási tapasztalatokkal rendelkezik, a különböző utazási motivációk eltérô fontossággal bírnak számára, így utazási karrier minták rajzolódnak ki. A push utazási motivációk fontosságuk alap- 
Lektorált tanulmányok

ján rétegekbe sorolhatók. A legbelső (core) rétegbe tartozik a menekülés, a pihenés, az újdonság iránti igény, a kapcsolatok építésének igénye, amely minden turista számára mindig nagyon fontos, függetlenül attól, hogy milyen utazási tapasztalatai vannak, illetve mennyit utazott korábban. A középsô rétegbe kerülő motivációk közepesen fontosak, és ezek további két csoportba sorolhatóak:

- A szerényebb utazási karrierrel rendelkezók számára fontosabbak a „belső" irányába orientáló tényezők (önfejlesztés, önmegvalósítás vágya).

- A gazdagabb utazási karrierrel rendelkezók számára a „kifelé” irányuló motivációk, a természet iránti vágy, az utazás helyszínén megvalósuló önfejlesztés, és a kapcsolat biztonságának vágya a fontosabb.

A külső rétegben találhatóak a legkevésbé fontos motivációk, például az elszigeteltség, a nosztalgia, a romantika és a felismerés vágya.

Az előzőekben a néhány mondattal jellemzett fontosabb koncepcionális mérföldkövek mellett számos tanulmány vizsgálta az utazási motivációkat (például UYSAL - HAGAN 1993, WILKIE 1994, KIM - LEE 2002). A turisztikai motivációkkal foglalkozó korai publikációk meghatározó befolyást gyakoroltak az ezredfordulót követően lefolytatott empirikus vizsgálatokra is, amelyek a turisztikai motivációkat többségében a push és pull fogalmi keretben vizsgálták. A főként kvantitatív, statisztikai módszerekkel lefolytatott vizsgálatok a push és pull faktorok azonosítására tettek kísérletet, a jellemzóen azonosított utazási motivációkat az 1. táblázatban mutatjuk be.

\section{Módszertan}

A motivációk vizsgálatának általános technikáját a közepes vagy nagymintás kérdőíves vizsgálatok jelentik, amelyek rendszerint nagyszámú (egyes vizsgálatokban ötvennél is több) push és pull motivációkat leíró állításokat (tételeket) tartalmaznak. A válaszadóknak az egyes motivációs állításokkal kapcsolatos egyetértésüket (önértékelés), vagy a nekik tulajdonított fontosságot (fontosság értékelés) 4-7 fokozatú Likert-skálák segítségével kell megadniuk (HUANG 2009). A skálák segítségével összegyújtött kvantitatív adatokat intervallum- vagy arányskálaként kezelve fejlettebb statisztikai módszerek, például korrelációelemzés, faktoranalízis, varianciaanalízis, klaszterelemzés alkalmazására adnak lehetőséget.
1. táblázat

Push és pull utazási motivációk fogalmi kerete

\begin{tabular}{|c|c|}
\hline Ösztönző (push) tényezők & Húzó (pull) tényezők \\
\hline Motivációk & $\begin{array}{c}\text { A desztináció jellemzői } \\
\text { és szolgáltatásai }\end{array}$ \\
\hline Menekülés vágya & Klíma \\
\hline Pihenés és kikapcsolódás & Történelmi látnivalók \\
\hline Önbecsülés & A táj szépsége \\
\hline Presztízs & Napfény \\
\hline Egészség és fittség & Tengerpartok \\
\hline Kaland & Hó \\
\hline Társadalmi kapcsolatok & Kulturális események \\
\hline Hasznok & $\begin{array}{l}\text { Pihenési, rekreációs } \\
\text { lehetőségek }\end{array}$ \\
\hline Érdekek & Haszonvárakozások \\
\hline $\begin{array}{c}\text { Társadalmi-gazdasági és } \\
\text { demográfiai tényezók }\end{array}$ & Elérhetôség \\
\hline $\begin{array}{l}\text { Kor, nem, jövedelem, } \\
\text { képzettség, családi életciklus } \\
\text { és nagyság, rassz/etnikai } \\
\text { csoport, foglalkozás, második } \\
\text { otthon tulajdonlása }\end{array}$ & $\begin{array}{l}\text { Fenntartási és helyzeti } \\
\text { tényezők } \\
\text { Biztonság, szezonalitás }\end{array}$ \\
\hline Piacismeret & $\begin{array}{c}\text { A piac számára } \\
\text { közvetített imázs } \\
\text { Negatív/pozitív irányba } \\
\text { formált desztinációs imázs } \\
\text { Szolgáltatások minoosége } \\
\text { Létesítmények minósége }\end{array}$ \\
\hline
\end{tabular}

Forrás: UYSAL et al. 2008

A nemzetközi szakirodalomban számos hasonló empirikus vizsgálat érhető el (például PYO et al. 1989, OH et al. 1995, BALOGLU - UYSAL 1996, UYSAL - JUROWSKI 1994, YOU et al. 2000, id.: UYSAL et al. 2008, BASHAR - AHMED 2010). A kutatások a push és pull faktorok azonosításán túl gyakran azt is vizsgálták, hogy a faktorok segítségével hogyan szegmentálható a turisztikai piac, például mennyiben különböznek egymástól a nók és a férfiak utazási motivációi (McGEHEE et al. 1996), mennyiben különböznek egymástól speciális célcsoportok, például egyetemi hallgatók különféle szegmenseinek utazási motivációi (DEJTISAK et al. 2009). Fejlettebb statisztikai módszerek alkalmazásával (például strukturális egyenletek modellezésével) többen vizsgálták a motivációk, a turisztikai elégedettség és a visszatérési hajlandóság (desztináció iránti lojalitás) kapcsolatát (például YOON - UYSAL 2005, OOM DO VALLE et al. 2006). 
Lektorált tanulmányok

Mivel Magyarországon a témában hasonló jellegú vizsgálat még nem történt, így a nemzetközi szakirodalmi elózmények alapján kvantitatív felmérés segítségével vizsgáltuk a magyarok szabadidős utazásai mögött meghúzódó motivációkat.

$\mathrm{Az}$ adatgyúitésre strukturált kérdőívet állítottunk össze. A kérdőív szúrôkérdéssel indult, majd az utazás alapvetô jellemzőire vonatkozó kérdéseket követően 56, részben push, részben pull motiváció körébe sorolható állítást tartalmazott. A motivációk mérésére vonatkozó állítások nagyrészt YOON és UYSAL (2005) vizsgálatára épültek, ahol szükséges volt, ott a magyar turisztikai és társadalmi környezethez igazítottuk. A push motivációkat reprezentáló elemek az utazás megszervezésére vonatkozó motivációs állításokként szerepeltek a kérdőívben („,A felsorolt motivációk mennyire voltak fontosak az utazás megszervezése során?"), míg a pull motivációk az utazás helyszínének megválasztására vonatkozó állításokként szerepeltek (, $\mathrm{A}$ felsorolt tényezők mennyiben befolyásoltak az utazás helyszínének megválasztását?"). Az állításokat a válaszadóknak ötfokozatú Likert-skálán kellett értékelniük. A kitöltóket arra kértük, hogy a megelőző egy év viszonylatában az általuk legfontosabbnak tartott szabadidős utazásukra vonatkozóan adják meg válaszaikat. A kérdőív demográfiai kérdésekkel (kor, nem, lakhely, családi állapot, jövedelem) kérdésekkel zárult.

Az elkészült kérdőívet az interneten tettük közzé, a válaszadók megkeresésére és a kérdőív kitöltésének ösztönzésére főiskolai hallgatókat kértünk fel. A válaszadók kiválasztásakor az aktív korúak megkérdezésére törekedtünk, mivel koruk, jövedelmük és egészségi állapotuk alapján túlnyomó többségében közülük kerülnek ki a szabadidős turisták. Nemenként azonos számú válaszadót kérdeztünk meg, valamint a korcsoportok szerinti reprezentativitásra törekedve három korcsoportot képeztünk (19-34, 35-49 és 50-64 év közöttiek), és ezeken belül is azonos számú válaszadó megkérdezésére törekedtünk, amely arány hozzávetóleg megegyezik az aktív korúak összlakosságon belüli megoszlásával. A kitöltés során arra is figyeltünk, hogy egy családból csak egyvalaki tölthesse ki a kérdőivet. A területi reprezentativitás biztosítására sajnos nem volt módunk, így a kérdőívet kitöltók fóként a városokból, illetve a Közép-magyarországi Régióból kerültek ki. A vizsgálat céljai a következôk voltak:

- Azonosíthatóak-e a nemzetközi szakirodalomban leírt push és pull utazási motivációk a magyar szabadidôs utazáson részt vett turisták körében?
- Megfigyelhetőek-e, és ha igen, milyen irányúak és nagyságúak a motivációs eltérések a válaszadók különféle csoportjai között?

- A motivációs eltérések alapján megfogalmazhatóak-e olyan releváns szabadidős turista szegmensek, amelyek marketing szempontból is értékesek lehetnek?

\section{Eredmények}

Az adatfelvétel során 1096 értékelhetó választ gyúitöttünk össze. A válaszadók 80\%-a, 896 fő, utazott szabadidős céllal az elmúlt egy évben. Akik nem utaztak, azok jórészt anyagi, családi, egészségügyi, vagy hivatalos elfoglaltságot jelöltek meg az utazás akadályául. A szabadidős utazáson részt vevők többségében Magyarországon belül utaztak (61\%), de elófordultak olyan válaszadók is, akik egy utazás során több országot is felkerestek. Az utazások több mint $60 \%$-a tengerpartokra vagy tópartokra (jellemzően a Balatonra) irányult, míg a válaszadók majdnem harmada városlátogatást jelölt meg. $\mathrm{Az}$ utazások többnyire társasággal történtek (családdal, párral, barátokkal, ismerősökkel), elenyészó számban jelöltek meg egyedüli vagy csoportos utazást. Az utazások $60 \%$-a nyárra esett, téli utazásról mindössze az összes válaszadó 5\%-a számolt be. A szabadidós utazáson részt vevók 35\%-a volt 1934 év közötti, 34\%-uk volt 35-49 év közötti, míg az 50-65 évesek aránya 31\% volt. A 19-34 éves közötti kitöltők kétharmada diák volt, ami fóképp az adatgyúijtésben közremúködő fóiskolai hallgatók miatt alakult így. A megkérdezettek $41 \%$-a a fővárosban, $14 \%$ megyeszékhelyen, míg egyéb városban $29 \%$ lakott, a kisebb települések részaránya $15 \%$ volt. A megkérdezett, szabadidôs utazásokon részt vevők az átlagosnál magasabb iskolai végzettséggel rendelkeztek, több mint 50\%-uk rendelkezett érettségivel, de a felsőfokú végzettségúek aránya is meghaladta a 40\%-ot. Ebben az értelemben a felmérés az átlagosnál magasabb végzettségú és státuszú, fóképp a városokban (azon belül is Közép-Magyarországon és Budapesten) éló magyarok utazási motivációit vizsgálta.

Ahhoz, hogy az utazási motivációkra vonatkozó állítások mögött azonosítani tudjuk a motivációs faktorokat, az első lépésben faktoranalízist hajtottunk végre. A push és pull motivációra vonatkozó állításokat SPSS segítségével külön-külön elemzésben vizsgáltuk.

A push változók alkalmasnak bizonyultak a faktoranalízis elvégzésére (a KMO teszt értéke 0,766, a Bartlett-próba szignifikancia szintje 0,000 volt). A kiinduló változók között közepes mértékú korreláció volt megfigyelhető. Extrakciós módszernek a főkomponens analízist választottuk, Varimax ro- 
Push faktorok

\begin{tabular}{|c|c|}
\hline Push faktorok és a faktorokat alkotó legnagyobb faktorsúlyú változók & $\begin{array}{c}\text { Magyarázott variancia (\%) } \\
\text { Változók faktorsúlya }\end{array}$ \\
\hline PUSH - 1: “Társas kapcsolatok, barátok, kaland” & $\mathbf{1 4 , 6 9 \%}$ \\
\hline Ismerkedni, flörtölni & 0,819 \\
\hline Szórakozni és bulizni & 0,705 \\
\hline Izgalmakat és új kihívásokat keresni & 0,667 \\
\hline Megismerkedni új emberekkel & 0,621 \\
\hline Együtt lenni barátokkal & 0,561 \\
\hline Együtt lenni a családdal/párommal & $-0,553$ \\
\hline PUSH - 2: “Újdonság keresése” & $\mathbf{1 2 , 6 4 \%}$ \\
\hline Történelmi, kulturális helyszíneket felkeresni & 0,797 \\
\hline Eljutni olyan helyekre, ahol még nem jártam/jártunk & 0,741 \\
\hline Újételeket megkóstolni & 0,729 \\
\hline Annyi újat látni és megélni, amennyit csak lehetséges & 0,620 \\
\hline PUSH - 3: “Menekülés” & $\mathbf{1 1 , 6 9 \%}$ \\
\hline Kiszakadni a mindennapi rutinból & 0,844 \\
\hline Kiszakadni a monoton otthoni rutinból & 0,835 \\
\hline Élvezni, hogy mást csinálhatok/csinálhatunk, mint amit a hétköznapokban & 0,706 \\
\hline PUSH - 4: “Otthonosság és biztonság” & $\mathbf{8 , 8 6 \%}$ \\
\hline Otthon érezni magam/magunk az otthontól távol & 0,841 \\
\hline Biztonságban érezni magam/magunk & 0,749 \\
\hline PUSH - 5: “Rokonlátogatás, újrafelfedezés” & $\mathbf{8 , 0 0 \%}$ \\
\hline Rokonokat meglátogatni & 0,764 \\
\hline Újra felfedezni rég látott helyeket & 0,590 \\
\hline PUSH - 6: “Mozgás” & $\mathbf{7 , 4 6 \%}$ \\
\hline Fizikai aktivitást úzni (kirándulás, sielés, kerékpározás, stb.) & 0,729 \\
\hline Semmit sem csinálni & $-0,729$ \\
\hline
\end{tabular}

Forrás: saját adatgyújtés

tációval és Kaiser normalizációval. A sajátérték-küszöbre épülő Kaiser-kritérium alapján az SPSS ötfaktoros megoldást javasolt, azonban a változók faktorsúlyainak tanulmányozását követően egy változót kizártunk az elemzésból (az „Önmagam újrafelfedezése" változó 0,5 alatti faktorsúlyával nem volt egyértelmúen hozzárendelhetó egyik faktorhoz sem). Az elemzést újra lefolytatva a könyökdiagram alapján végül hat faktoros megoldást választottunk. A kiválasztott hat faktor az eredeti változók összvarianciájának 63,3\%-t magyarázta. A hat push faktort és a hozzájuk tartozó legnagyobb faktorsúllyal rendelkezó 19 változót a 2. táblázat tartalmazza.

A 26 db pull változó szintén alkalmasnak bizonyult a faktoranalízis elvégzésére. A változók közötti korreláció erôs volt (a KMO teszt értéke 0,883, a Bartlett-próba szignifikancia szintje 0,000 értékú volt). Extrakciós módszernek szintén főkomponens analízist választottunk, Varimax rotációval és Kaiser normalizációval. Az SPSS által javasolt hat faktoros megoldást a Kaiser-kritérium és a könyökdiagram tanulmányozása alapján elfogadtuk, a modell a kiinduló változók összvarianciájának 61,95\%-át magyarázta. A hat pull faktort és a hozzájuk tartozó változókat a 3. táblázat tartalmazza. A kapott faktorok és az óket alkotó változók faktorsúlyai alapján jól interpretálhatóak a szakirodalmi áttekintésben ismertetett push és pull motivációk. Az általunk azonosított faktorok esetenként egyszerre több, a szakirodalomban megjelenó motivációt is megjelenítenek (lásd az 1. táblázatot!). Ez azonban nem hiba, és nem is mond ellent a korábbi empirikus tapasztalatoknak.

A következó lépésben a faktorokat alkotó változók faktorsúlyai és az eredeti változók értékei alapján meghatároztuk, hogyan alakulnak a push és pull faktorok (motivációk) értékei a válaszadók körében. A faktorértékek számítása során az SPSS regressziós módszerét alkalmaztuk. Az eljárás jellegzetessége, hogy az egyes faktorok faktorértékeinek átlaga nulla értékú lesz, és az egyes 
Lektorált tanulmányok

\section{Pull faktorok}

\begin{tabular}{|c|c|}
\hline Pull faktorok és a faktorokat alkotó legnagyobb faktorsúlyú változók & $\begin{array}{l}\text { Magyarázott variancia (\%) } \\
\text { Változók faktorsúlya }\end{array}$ \\
\hline PULL - 1: „Turisztikai vonzerök" & $28,88 \%$ \\
\hline Felkereshetô szép, történelmi városok & 0,813 \\
\hline Érdekes, szép városok és falvak & 0,775 \\
\hline Meglátogatható nagyváros(ok) & 0,744 \\
\hline A hazaitól eltéró, érdekes helyi kultúra & 0,647 \\
\hline A helyi konyha, helyi gasztronómiai kínálat & 0,550 \\
\hline Érdekes és barátságos helyi emberek & 0,408 \\
\hline PULL - 2: „Turisztikai szolgáltatások, higiénia, biztonság, személyes tér” & $9,28 \%$ \\
\hline Kiváló minôségú szálláslehetôségek & 0,734 \\
\hline Tisztaság, higiénia & 0,721 \\
\hline Jó minőségú éttermek & 0,644 \\
\hline Magánélet lehetôsége (elvonulási lehetôség) & 0,642 \\
\hline Biztonság (személyes és/vagy a családé) & 0,632 \\
\hline Nincs tömeg & 0,466 \\
\hline Vásárlási lehetôségek & 0,419 \\
\hline PULL - 3: „Vízpart, egzotikus környezet és klíma” & $7,14 \%$ \\
\hline Tengerpart & 0,855 \\
\hline Kedvezö időjárás, klíma & 0,732 \\
\hline Egzotikus környezet & 0,710 \\
\hline Jó minőségú strandok & 0,612 \\
\hline PULL - 4: „Megfizethetôség” & $6,56 \%$ \\
\hline Olcsó szálláslehetôségek & 0,791 \\
\hline Közelség, könnyủ megközelíthetôség & 0,733 \\
\hline Olcsó éttermek & 0,607 \\
\hline Korábbi helyszíni tapasztalatok & 0,408 \\
\hline PULL - 5: „Hegyvidék és mozgás lehetősége” & $5,99 \%$ \\
\hline Hegyvidék & 0,811 \\
\hline Fizikai aktivitás lehetôsége (kirándulás, sílés, kerékpározás, stb.) & 0,717 \\
\hline Gyönyörü tájak & 0,555 \\
\hline PULL - 6: „Buli és szórakozás” & $4,11 \%$ \\
\hline Szórakozás, buli, éjszakai élet & 0,799 \\
\hline Fesztiválok, koncertek vagy más szabadtéri rendezvények & 0,774 \\
\hline
\end{tabular}

Forrás: saját adatgyújtés

válaszadókra kiszámolt faktorérték jellemzően vagy pozitív (a motiváció az átlagosnál fontosabb a válaszadó számára), vagy negatív előjelú lesz (a motiváció az átlagosnál kevésbé fontos a válaszadó számára). Az eljárással a kiinduló közel ötven változót hat push és hat pull faktorra (motivációra) redukáltuk, válaszadónkénti faktorértékekkel (3. táblázat).

Az elemzés következô szakaszában arra voltunk kíváncsiak, hogy a válaszadók különféle csoportjai között milyen eltérések mutatkoznak az egyes faktorok, mint utazási push és pull motivációk átlagértékeiben. A válaszadókat a kérdőív demográfiai adatai (nem, kor, jövedelem és legmagasabb iskolai végzettség) alapján csoportokba soroltuk, majd egyszempontos varianciaanalízis segítségével vizsgáltuk a csoportátlagok különbségeit. Mivel a normalizált faktorértékek lényegesen eltértek az alapváltozók 1-5-ös skálaértékeitől (egyebek mellett minden faktorváltozó esetében más és más volt a legkisebb és a legnagyobb érték), így az egyes válaszadói csoportátlagok eltéréseinek nagyságát a motivációs változók minimális és maximális értékei eltérésének (a változó terjedelmének) százalékában adtuk meg. Az eredményeket a 4. táblázat tartalmazza. 


\section{A varianciaanalízis által feltárt különbségek a demográfiai változók alapján képzett} válaszadói csoportokban

\begin{tabular}{|c|c|c|c|c|}
\hline \multirow[b]{2}{*}{ Motivációk } & \multicolumn{4}{|c|}{ Demográfiai csoportképző változók } \\
\hline & $\mathrm{Nem}^{1}$ & Korcsoport $^{2}$ & $\begin{array}{l}\text { Legmagasabb } \\
\text { isk. végzetts. }{ }^{4}\end{array}$ & $\begin{array}{l}\text { Egy före jutó } \\
\text { jövedelem }\end{array}$ \\
\hline PUSH - 1: "Társas kapcsolatok, barátok kaland" & $F:+2,91 \%$ & 18-34: $+11,49 \%$ & - & - \\
\hline PUSH - 2: "Újdonság keresése" & $N:+2,90 \%$ & $18-34:+6,08 \%$ & $F:+7,28 \%$ & $\begin{array}{l}M-K: 3,72 \% \\
M-A: 7,16 \%\end{array}$ \\
\hline PUSH - 3: "Menekülés" & $N:+3,66 \%$ & 50-64: $-5,54 \%$ & $F:+6,57 \%$ & - \\
\hline PUSH - 4: "Otthonosság és biztonság" & $N:+4,15 \%$ & - & $K:+5,70 \%$ & M: $-4,5 \%$ \\
\hline PUSH - 5: "Rokonlátogatás, újrafelfedezés" & - & $50-64:+4,02 \%$ & - & - \\
\hline PUSH - 6: "Mozogni" & - & - & $F:+5,59 \%$ & \\
\hline PULL - 1: "Turisztikai vonzerók” & $N:+3,95 \%$ & 50-64: $+5,29 \%$ & - & A: $-4,83 \%$ \\
\hline $\begin{array}{l}\text { PULL - 2: "Turisztikai szolgáltatások, higiénia, } \\
\text { biztonság, személyes tér" }\end{array}$ & $N:+3,65 \%$ & 50-64: $+2,19 \%$ & - & - \\
\hline PULL - 3: „Vizpart, egzotikus környezet és klíma” & $F:+3,44 \%$ & 50-64: $-4,60 \%$ & $F:+6,94 \%$ & $M:+6,14 \%$ \\
\hline PULL - 4: „Megfizethetôség” & - & - & $F:-3,65 \%$ & M: $-6,32 \%$ \\
\hline PULL - 5: „Hegyvidék és mozgás lehetôsége” & $F:+3,00 \%$ & 18-34: $-4,67 \%$ & - & - \\
\hline PULL - 6: „Buli és szórakozás” & - & $\begin{array}{c}\text { 18-34: }+9,35 \% \text { és } \\
+14,41 \% \%^{3}\end{array}$ & - & - \\
\hline
\end{tabular}

Forrás: saját adatgyújtés

\footnotetext{
${ }^{1}$ A másik nem átlagától való eltérés százaléka (a nemek átlagai közötti eltérés a változó teljes terjedelmének százalékban van kifejezve, ahol a változó teljes terjedelme = 100); N: nők átlaga magasabb, F: férfiak átlaga magasabb.

${ }^{2}$ A másik két korcsoport átlagának átlagától való eltérés százaléka (a korcsoportok átlagai közötti eltérés a változó teljes terjedelmének százalékában van kifejezve, ahol a változó teljes terjedelme $=100$ ). 18-34: a Tukey B próba (ANOVA post-hoc elemzés) alapján a megjelölt korcsoport (például 18-34 évesek) átlaga tér el szignifikánsan a többi korcsoportétól.

${ }^{3}$ A 18-34 évesek csoportátlagának eltérése a másik két korcsoport önálló csoportátlagaihoz viszonyítva.

${ }^{4}$ A másik két legmagasabb iskolai végzettség alapján képzett válaszadói csoport átlagának átlagától való eltérés százaléka (az átlagok közötti eltérés a változó teljes terjedelmének százalékában van kifejezve, ahol a változó teljes terjedelme = 100), F: felsôfokú, K: középfokú, A: alapfokú. A Tukey B próba alapján a megjelölt iskolai végzettség alapján képzett csoport (például „, $\mathrm{F}^{\prime \prime}$, a felsőfokú végzettségúek) átlaga tér el szignifikánsan a többi csoportétól.

${ }^{5}$ A másik két átlagos egy főre jutó jövedelem alapján képzett válaszadói csoport átlagának átlagától való eltérés százaléka (az átlagok közötti eltérés a teljes terjedelem százalékában van kifejezve ahol a változó teljes terjedelme = 100), M: magas jövedelem (M > 200 eFt/fő/hó), K: közepes jövedelem (100 eFt/fő/hó < K < 200 eFt/fó/hó), A: Alacsony egy főre jutó jövedelem (A < 100 eFt/fő/hó). A Tukey B próba alapján a megjelölt egy főre jutó jövedelem alapján képzett csoport (például „M”, magas egy főre jutó jövedelem) alapján képzett válaszadói csoport átlaga tér el szignifikánsan a többi csoportétól.

${ }^{6} \mathrm{~A}$ magas egy fốre jutó jövedelmú válaszadói csoport (M) átlaga a másik két jövedelmi csoport önálló csoportátlagához viszonyítva.

- 95\%-os szignifikancia szinten nincs szignifikáns különbség a válaszadói csoportok átlagai között.
}

A táblázat adatai azt mutatják, hogy a demográfiai ismérvek alapján képzett válaszadói csoportok csoportátlagai között nincsenek jelentős eltérések. A legnagyobb eltérés nem éri el a 15\%-ot, amely az ötfokozatú skálán 0,75-ös különbségnek felel meg. A feltárt, és a varianciaanalízis eredményei alapján szignifikánsnak bizonyult csoportátlag-különbségek mintegy fele $5 \%$ alatti, ami ötfokozatú skálán mérve mindössze 0,25-ös eltérést vagy kevesebbet jelentene.

A nemek csoportátlagai közötti eltérések mindössze a 3-4\%-os sávba esnek. A nagyobb, de 5\%-ot így sem elérő különbség az „Otthonosság és biztonság" push motiváció csoportátlagainál figyelhető meg, ez a motiváció a női válaszadók számára fontosabb. Hasonló eredményt látunk a „Turisztikai vonzerők”, a „Menekülés”, a „Turisztikai szolgáltatások, higiénia, biztonság, személyes tér" motivációk esetében is, melyek szintén valamivel fontosabbak a nők körében. Ugyanakkor a vízpart és a hegyvidék kicsivel jobban vonzza a férfiakat. Jelentôsebb különbségek mutatkoznak a korcsoportok csoportátlagai között. A legnagyobb kü- 
Lektorált tanulmányok

lönbség a „Társas kapcsolatok, barátok, kaland” push motiváció esetén mutatkozik, ahol a 18-34 éves korosztály csoportátlaga 11,5\%-kal haladja meg a 35-49 és az 50-64 éves korosztály csoportátlagának átlagát. Az ezzel szorosan összefüggő, „Buli és szórakozás” pull motiváció esetében 15\%-os eltérés mutatkozik a 18-34 éves fiatalok, valamint az 50-64 éves korosztály csoportátlagai között. Ez jól jelzi a gyakorlatban is megfigyelhetô, fiatalok körében jellemző magatartást, amely szerint a fiatalok az utazások során jobban keresik és igénylik a társas kapcsolatokat, az izgalmat és kalandot, míg az idősebbek ilyen irányú motivációi (már) kevésbé hangsúlyosak. Szintén szignifikánsan magasabb a fiatal korosztály csoportátlaga az „Újdonság keresése" motiváció esetében, míg az idôsebb korosztály számára a desztináció által kínált vonzerók fontosabbak. A menekülés vágya a két fiatalabb korcsoport esetében fontosabb, az 5064 éves korosztály csoportátlaga 5,5\%-kal maradt el a másik két korosztály csoportátlagának átlagától. A legmagasabb iskolai végzettség alapján képzett válaszadói csoportok átlagai alapján a felsőfokú végzettségúek körében fontosabb az újdonság keresése, a menekülés, a mozgás vágya, illetve a vízpart, mint desztinációs vonzeró, míg az alacsonyabb végzettségúek körében az otthonosság és biztonság igénye szignifikánsan magasabb. Az eredményt azonban árnyalja, hogy mindössze a válaszadók 1,3\%-a volt alapfokú végzettségú, a középfokú végzettségúek aránya meghaladta az $50 \%$-ot a felső́fokú végzettségúek $48 \%$-os aránya mellett.

A háztartás egy fơre jutó havi jövedelme alapján képzett válaszadói csoportok esetében a legmagasabb (több mint 200 e Ft/fő/hó) egy fơre jutó jövedelemmel rendelkezó válaszadói csoport körében volt magasabb az újdonság iránti vágy, valamint a vízpart, mint speciális desztinációs vonzerő fontossága. Ugyanakkor nem feltétlenül az olcsó utazási lehetőséget és desztinációkat keresik, emellett számukra kevésbé fontos, hogy ugyanarra a helyre térjenek vissza, összehasonlítva az alacsonyabb jövedelmú válaszadói csoportok átlagaival.

\section{Szegmentumok azonosítása a motivációs faktorok alapján}

A 4. táblázatban megfigyelhető motivációs eltérések alapján komplexebben, több változó segítségével leírható szegmentumok is körvonalazhatók, amelyek már a turisztikai marketing számára is hasznosítható ismérvekkel rendelkezhetnek. Áttekintve a válaszadói csoportok közötti eltéréseket, a következó szegmensek azonosíthatók:
- Szabadidôs utazásaik során kalandot, társaságot, szórakozást és bulit keresó fiatalok: fiatal felnőttek, jellemzően diákok, még nem befejezett felsőfokú (középfokú) tanulmányokkal. Jellemző rájuk, hogy utazásaik során keresik és igénylik az újdonságot, a társas kapcsolatokat és a szórakozási lehetőségeket.

- Újdonságot, egzotikus környezetet, különösen a vízpartokat és a mozgást kedveló magasabb jövedelmúek: jellemzóen felsőfokú végzettségúek, akik menekülnek a mindennapokból, változatosságra vágynak, szeretik a víz- (tenger-) partokat, és utazásaik során hajlandóak jobban a zsebükbe nyúlni. Szabadidôs utazásaik során a "mást” (nem az otthonit) keresik, és legalább közepesen fontos számukra a szolgáltatások minősége.

- A turisztikai vonzerók iránt érdeklődó középkorosztály: utazásaik jellemzô célpontját nem a vízpartok képviselik, ugyanakkor vonzzák őket az épített, táji, kulturális és gasztronómiai vonzerók (lásd a PULL - 1 faktort!), azaz látni és tapasztalni akarnak, utazási motivációik között nem domináns a menekülés vágya. - A megszokottat keresô, rokonlátogató késô középkorosztály: az eredmények alapján nehezebben körvonalazható csoport, jellemzően női preferenciák alapján megfogalmazható szegmens, vélhetôen közepes és alacsonyabb jövedelemmel. Szabadidős utazásaik során fontos az otthonosság, a biztonság, megszokott célpontokat keresnek fel, ami gyakran a rokonlátogatásokat jelenti.

A válaszadók körében azonosított motivációs eltéréseket és az ezek alapján megfogalmazott szabadidős turisztikai szegmenseket tanulmányozva a fiatal korosztályt könnyen beskatulyázhatjuk a bulizós, szórakozós, könnyed kapcsolatokat keresô, a tinédzserkorból épp csak kilépó, a hétköznapi családi közegból menekülő, "csajozós-pasizós", sokszor pejoratív jellemzőkkel illetett fiatal utazók kategóriájába, akik napjainkban a divatos és sikeres, turisztikai termékként is megjelenó nyári zenei fesztiválok tipikus közönségét alkotják. Ez azonban felületes kép. A kései tizen- és korai huszonéves fiatalok körében ez a viselkedés korántsem deviáns, a felnőtté válás egyik fontos szocializációs szakaszáról van szó, amelyben a fiatal a társas kapcsolatait ápolja (ezek a kapcsolatok gyakran fontosabbak és tartósabbak a késóbbi életszakaszokban kialakuló kapcsolatoknál), és igyekszik jól érezni magát, még ha ennek a viselkedésnek vannak is vadhajtásai. E motivációk kiélésének ideális terepe lehet a szabadidós utazás, és napjainkban különösen alkalmas helyszínt 
jelentenek a kulturális turizmus körébe tartozó többnapos zenei fesztiválok.

A termékmarketing már régóta tudatosan épít erre a korosztályra. A témában talán legismertebb reklámszlogenek „Haverok, buli, Fanta” (az egyik újabb angol verzióban: More Fanta, Less Serious!), vagy a „Kell egy hét együttlét”, amely a '90-es években a Sziget Fesztivál szlogenje volt (és egyben filmcím is), találóan reflektálnak a fiatalok vágyaira. Kutatásunkban a társas kapcsolatok, barátok, kaland, buli, szórakozás motiváció azért is jelenik meg enynyire plasztikusan, mert az adatgyújtést az érintett fiatal korosztály képviselői, főiskolai hallgatók végezték, és jelentős számban ook töltötték ki a kérdoóiveket a 18-34 éves korosztály tagjaiként. Vélhetôen, más összetételú megkérdezettek esetén valamivel másképp alakultak volna a motivációk fontossága és a demográfiai csoportok közötti eltérések.

A megfogalmazott további szegmenseknek akkor van relevanciája, ha a gyakorlat igazolja a létüket. Tekintetbe véve, hogy a hagyományosnak tekinthetó demográfiai ismérveket alkalmaztuk a szegmentáció során, a további három szegmens sem a valóságtól elrugaszkodott konstrukció. Számos, nem turisztikai példát találunk a különféle korcsoportokra, eltérố jövedelmi helyzetû, vagy eltérő iskolázottságú célcsoportokra reflektáló termékekre és szolgáltatásokra (lásd például az Elittárs társkereső honlapot, amely az átlag feletti jövedelmú diplomásokat célozza meg).

Az eredmények kapcsán fontos megjegyezni, hogy a varianciaanalízis eredményei arra vonatkoznak, hogy a vizsgált mintában látható különbségek szignifikánsnak tekinthetőek-e a populáció egészében is. Azonban mintánk nem minden szempontból volt reprezentatív, így az eredmények általánosíthatósága a varianciaanalízis által feltárt szignifikáns különbségek alapján is csak korlátozott.

\section{6. Összefoglalás, a kutatás korlátai és a tovabbi kutatási irányok}

Kutatásunk során a magyar lakosság szabadidős utazásai kapcsán egyértelmúen azonosítani tudtunk ösztönző (push) és húzó (pull) utazási motivációkat. A push motivációk között jelent meg a társas kapcsolatok igénye, az újdonság keresésének vágya, a menekülés és biztonság iránti vágy, míg a pull motivációk körében a desztinációs vonzerók és turisztikai szolgáltatások, valamint a megfizethetőség igénye voltak a legfontosabbak. A faktoranalízis eredményeként kimutatott motivációs faktorok illeszkednek a nemzetközi szakirodalom megállapításaihoz.
A kapott eredmények azonban nem pusztán reprodukálták a megelőző kutatások következtetéseit. Mind a faktorstruktúra, mind a körvonalazott szegmensek eltérnek a megelőző kutatások eredményeitől, ami nyilvánvalóan összefügg a kérdőívet alkotó attitúdállítások körével, a mintavétel sajátosságaival és a kérdőívben vizsgált utazással. Kérdőívünk a megelőző év legfontosabbnak tartott utazásával kapcsolatos motivációkra kérdezett rá, ám a motivációk utazásonként változnak, így más eredményre jutottunk volna, ha másképp, vagy más utazások körére fogalmazzuk meg a vizsgálati feltételt. Jelen kutatásunk során a válaszadók által legfontosabbnak tartott szabadidős utazások vonatkozásában nyertünk egy motivációs faktorstruktúrát, amelyet egyéb megfigyelések is visszaigazolnak.

Egy ugyanilyen módszertannal megismételt kutatás nem biztos, hogy pontosan ugyanerre az eredményre vezetne, vélhetően a faktorstruktúra és a demográfiai alapú szegmensek is változnának. Ez azonban jelen kutatás eredményeit nem teszi idézójelbe. Az azonos módszertannal lefolytatott társadalomtudományi kutatások eredményei nem mindig egyeznek, amit nemcsak a módszertan eltérései, hanem a megfigyelés tárgyának és alanyának változékony természete is magyaráz. Emiatt az utazási motivációk vizsgálatára is további kutatások javasolhatóak, a módszertan párhuzamos fejlesztésével.

A későbbi, motivációk vizsgálatára irányuló kutatások során célként fogalmazható meg minél több olyan ismérv beemelése a vizsgálatba, amely a szegmentálhatóságot javítja. Emellett érdemes úgy tervezni a felmérést, hogy további szegmentációs technikák (például klaszteranalízis, diszkriminanciaelemzés, logisztikus regresszió) is alkalmazhatóvá váljanak.

Jelen felmérés tapasztalatai alapján fontos feladat a reprezentativitás javítása is, egyebek mellett a megkérdezettek területi, jövedelmi és legmagasabb iskolai végzettség szerinti eloszlásának közelítése a vizsgált célcsoport tényleges megoszlásához, máskülönben a viszonylag nagy minta megkérdezése ellenére is korlátozott marad az általánosíthatóság.

Szintén fontos feladat a motivációk mérési technikáinak fejlesztése. Bár kutatásunkban a motivációkat mérô többtételes skála viszonylag jól vizsgázott, azonban kimaradt néhány fontos dimenzió (például a pihenéssel és a különféle turisztikai aktivitásokkal kapcsolatos kérdések), és a skálatételek megfogalmazását is javítani célszerú.

A jövőbeli, utazási motivációkkal kapcsolatos vizsgálatok során érdemes diverzifikált helyszíneken, diverzifikált célcsoportokat (például beutazó turisták) különböző időpontokban (utazás alatt, el- 
utazáskor, utazást követően) is megkérdezni. Az ilyen célzott vizsgálatok további képet adhatnak arról, hogy melyek azok a motivációs és egyéb tényezók, amelyek Magyarországot, valamint az ország egyes turisztikai fogadóterületeit vonzóbbá tehetik a potenciális hazai és külföldi turisták szemében.

\section{Felhasznált irodalom}

BALOGLU, S. - UYSAL, M. (1996): Market segments of push and pull motivations: A canonical correlation approach. International Journal of Contemporary Hospitality Management. 8(3). pp. 32-38.

BASHAR, A. - AHMED, P. (2010): An Analysis of Push and Pull Travel Motivations of Foreign Tourists to Jordan. International Journal of Business and Management. 5(12). pp. 41-50.

BOWEN, D. - CLARK, J. (2009): Contemporary Tourist Behaviour: Yourself and Others and Tourists. CABI. Cambridge University Press, Cambridge.

CROMPTON, J. L. - McKAY, S. L. (1997): Motives of visitors attending festival events. Annals of Tourism Research. 24(2). pp. 425-439.

CROMPTON, J. L. (1979): Motivations for pleasure vacation. Annals of Tourism Research. 6(4). pp. 408-424.

DANN, G. M. S. (1977): Anomie, ego-enhancement and tourism. Annals of Tourism Research. 4(4). pp. 184-194.

DANN, G. M. S. (1981): Tourist motivation an appraisal. Annals of Tourism Research. 8(2). pp. 187-219.

DEJTISAK, M. - HURD, A. R. - ELKINS, D. J. SCHLATTER, B. E. (2009): A Comparison of Travel Decisions Between U.S. and International Students. LARNet. The Cyber Journal of Applied Leisure and Recreation Research: http:// larnet.org/2009-02.html

FODNESS, D. (1994): Measuring tourist motivation. Annals of Tourism Research. 21(3). pp. 555581.

GOOSSENS, C. (2000): Tourism introduction and pleasure motivation. Annals of Tourism Research. 27(2). pp. 301-321.

HUANG, S. (2009): Measuring Tourism motivation: Do Scales matter? MPRA Paper No. 25198: http://mpra.ub.uni-muenchen.de/25198/

ISO-AHOLA, S. E. (1982): Toward a social psychological theory of tourism motivation: A rejoinder. Annals of Tourism Research. 9(2). pp. 256-262.

KIM, S. S. - LEE, C-K. (2002): Push and pull relationships. Annals of Tourism Research. 29(1). pp. 257-260.
MASLOW, A. (1954): Motivation and Personality. Harper, New York.

McGEHEE, N. G. - LOKER-MURPHY, L. - UYSAL, M. (1996): The Australian international pleasure travel market. Motivations from a gendered Perspective. Journal of Tourism Studies. 7(1). pp. 45-57.

OH, H. C. - UYSAL, M. - WEAVER, P. A. (1995): Product bundles and market segments based on travel motivations: A canonical correlation approach. International Journal of Hospitality Management. 14(2). pp. 123-137.

OOM DO VALLE, P. - SILVA, J. A. - MENDES, J. - GUERREIRO, M. (2006): Tourist Satisfaction and Destination Loyalty intention: A Structural and Categorical Analysis. International Journal of Business Science and Applied Management. 1(1). pp. 25-44.

PEARCE, P. L. - LEE, U. (2005): Developing the travel career approach to tourist motivation. Journal of Travel Research. 43(3). pp. 226-237.

PEARCE, P. L. (2005): Tourist Behaviour: Themes and Conceptual Schemes. Channel View, Clevedon.

PUCZKÓ L. - RÁTZ T. (2011): Az attrakciótól az élményig. A látogatómenedzsment módszerei. Akadémiai Kiadó, Budapest.

PYO, S. - MIHALIK, B. J. - UYSAL, M. (1989): Attraction attributes and motivations: A canonical correlation analysis. Annals of Tourism Research. 16(2). pp. 277-282.

TOLMAN, E. C. (1959): Principles of purposive behavior. In: Koch, S. (ed): Psychology: A Study of a Science. 2. McGraw-Hill, New York. pp. 92-157.

UYSAL, M - LI, X. - SIRAKAYA-TURK, E. (2008): Push-pull dynamics in travel decision. In: Oh, H. - Pizam, A. (eds), Handbook of Hospitality Marketing Management. pp. 412-439.

UYSAL, M. - HAGAN, L. A. (1993): Motivations of pleasure travel and tourism. In: Khan, M. Olsen, M. - Var, T. (eds): Encyclopedia of Hospitality and Tourism. pp. 798-810.

UYSAL, M. - JUROWSKI, C. (1994): Testing the push and pull factors. Annals of Tourism Research. 21(4). pp. 844-846.

WILKIE, W. L. (1994): Consumer behavior. Wiley, New York.

YOON, Y. - UYSAL, M. (2005): An examination of the effects of motivation and satisfaction on destination loyalty: a structural model. Tourism Management. 26(1). pp. 45-56.

YOU, X. - OULEARY J. - MORRISON, A. - HONG, G-S. (2000): A crosscultural comparison of travel push and pull factors: United Kingdom vs. Japan. International Journal of Hospitality and Tourism Administration. 1(2). pp. 1-26. 